\title{
İnsülin Direnci ve Klinik Önemi
}

\author{
Insulin Resistance and Clinical Significance
}

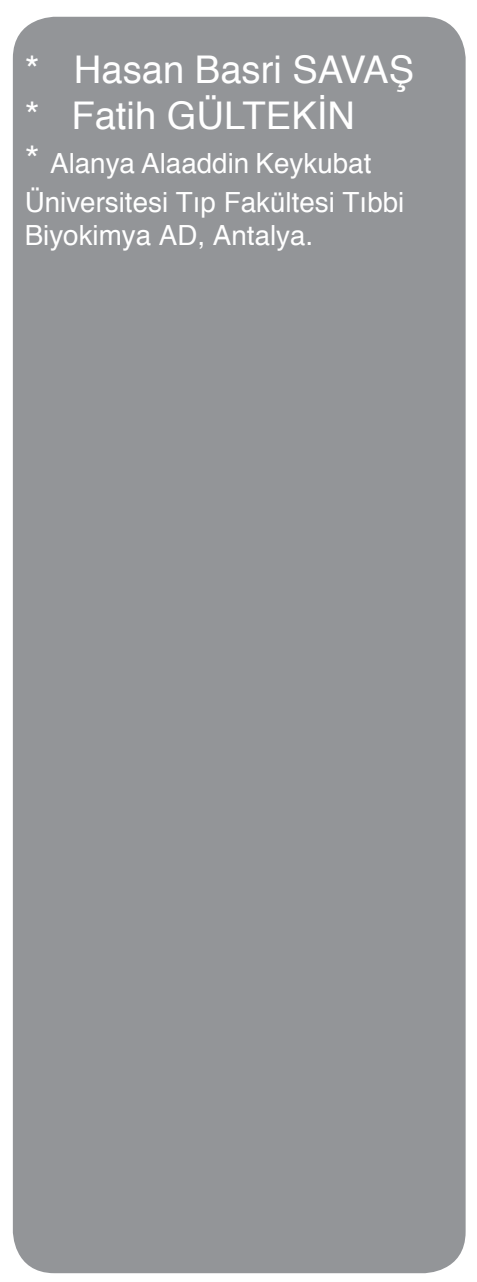

Yazışma Adresi:

Hasan Basri SAVAȘ

Alanya Alaaddin Keykubat

Üniversitesi Tıp Fakültesi Tıbbi

Biyokimya Anabilim Dalı

Alanya / Antalya

e-mail: hasan.savas@alanya.edu.tr

\section{Öz}

İnsülin metabolizmanın düzenleyici temel hormonlarından biridir. İnsülinin keşfi için uzun asırlar boyu süren araştırmalar mevcuttur. Bilim adamlarını insülini araştırmaya iten sebep insülin direncinin ortaya çıkardığı hastalıklardır. İnsülin direnci, karmaşık bir patogeneze sahiptir. İnsülin direncinin patogenezi halen tam olarak aydınlatılamamıştır ve araştııımaktadır. Obezite ile insülin direnci arasında çok güçlü bir ilişki bulunmaktadır. İnsülin direncinin en sık sebebi obezitedir. İnsülin direnci ortaya çıktığında hemen klinik belirti vermeyebilir. Subklinik dönemde diyet düzenlenmesi ve egzersizi içeren yaşam tarzı değişiklikleri ve kilo verilmesi ile insülin direnci gerileyebilir. İnsülin direncine müdahale edilmediğinde, uzun dönemde birçok hastalığa sebep olabilir. Kardiyovasküler hastalık riski artar. Endotel fonksiyonu bozulur. Tip 2 Diyabetes Mellitus gelişir. Metabolik sendrom sıklığı gittikçe artmaktadır. Metabolik sendromun en önemli bileşeni insülin direncidir. İnsülin direncinin ölçümü için altın standart olan metot, öglisemik hiperinsülinemik klemp metodudur. Bu metodun zahmetli ve pahalı olması sebebiyle HOMA (Homeostasis Model Assessment) metodu kullanılmaktadır. HOMA formülü açlık serum glikozu ve açıı serum insülini değerleri ile hesaplamaya dayanır. İnsülin direnci varlığında, yaşam tarzı değişiklikleri ile insülin direncini geriletme hedeflenir. Şayet geriletilemeyecek duruma gelmiş ve klinik problemler ortaya çıkmışsa hastalığa uygun ilaç tedavisi verilebilir. İnsülin direnci temelinde ortaya çıkan hastalıkların medikal tedavisine ek olarak yaşam tarzı değişiklikleri ilaçların etkinliğini arttırmaktadır. İnsülin direncine karşı yapılacak yaşam tarzı değişiklikleri, kilo verilmesi, diyet düzenlenmesi ve düzenli egzersiz olarak sayılabilir.

Anahtar Kelimeler: Insülin direnci, diyabet, obezite, kanser, HOMA formülü.

\begin{abstract}
Insulin is one of the basic editor hormones of metabolism. There are many researches for the discovery of insulin, based on many centuries. The reasons of scientists' insulin researches are the relation of clinical disease with insulin resistance. Insulin resistance has a complex pathogenesis. The pathogenesis of insulin resistance has not been fully clarified and investigated. Insulin resistance has a strong relation with obesity. The most common cause of insulin resistance is obesity. When Insulin resistance occured, it might not immediately show the clinical symptoms. Subclinical term regulation of diet and lifestyle that includes exercise and weight changes can be decreased by the administration of insulin resistance. If we don't regulate insulin resistance, it may cause many diseases in the long term. The risk of cardiovascular disease was increased in insulin resistance. Endothelial function is impaired. Type 2 diabetes mellitus develops. Prevalence of metabolic syndrome is increasing. The most important component of the metabolic syndrome is insulin resistance. The gold standard for the measurement of insulin resistance method is a method euglycemic hyperinsulinemic clamp. This
\end{abstract}


method is laborious and expensive due to the HOMA (Homeostasis Model Assessment) method is used. HOMA are based on calculations with fasting serum glucose and fasting serum insulin values. With lifestyle changes aimed towards insulin resistance is decreased. If the regression becomes unable to diseases and clinical problems arise we can give appropriate medication. On the basis of insulin resistance in addition to the medical treatment of diseases associated lifestyle changes increases the effectiveness of drugs. Insulin resistance can be done against lifestyle changes, weight management, diet and regular exercise may be considered.

Keywords: Insulin resistance, diabetes, obesity, cancer, HOMA formula.

\section{Giriş}

\section{İnsülinin Keşfi ve Nobel Ödülü Öyküsü}

Dünya genelinde diyabet hastası sayısı son 20 yılda iki katından fazla artmıştır. Oldukça endişelendirici diğer bir gelişme Tip 2 diyabetin beklenmedik şekilde gençlerde ve çocuklarda görülmeye başlanmasıdır. Diyabet hastası artışındaki ivmenin giderek yükseleceği tahmin edilmektedir (1, 2). Diyabet ile ilgili bilgiler MÖ 1500 yılından başlayarak, 21. Yüzyıla kadar ulaşmaktadır. 1921 yılında, Frederick
Grant Banting ve ekibinin uzun uğraşlar sonucu insülini keşfetmeleri diyabet hastalığının mekanizmasını ve tedavisini ortaya koyan önemli bir gelişme olmuştur (3, 4). Tablo 1'de insülinin keşfi ve kullanımı ile ilgili kronolojik bilgiler özetlenmiştir.

\section{Glikoz}

Normal sağlıklı bir bireyde kan glikoz düzeyi 70-100 mg/ dl'dir. Yemeği izleyen ilk 1-2 saat içinde kan glikoz düzeyi \% 160-170 mg/dl'yi aşmadan belirli bir seviyeye kadar artarak 2 saat içinde normal sınırlara iner. Öğünler arasında ve uzun süreli açlıkta da kan glikoz seviyesi normal sınırlar içinde tutulur. Glikozun bu düzenlenmesi beyin, eritrosit, retina gibi enerji kaynağı olarak öncelikle glikoz kullanan organlar için çok önemlidir. Dinlenme koşullarında organizmada kullanılan glikozun \% 60 kadarını beyin kullanır (5).

\section{İnsülin}

İnsülin geni, insülinin sentezlendiği ve salınmadan önce granüllerde depolandığı pankreatik beta adacık hücrelerinde eksprese edilir. Beta hücrelerinden insülin salınımı kan glikoz düzeyindeki artış ile başlar. Eğer sekretuar uyarı devam ederse gecikmiş ve uzamış bir cevap olarak aktif insülin sentezi başlar. İnsülin sentezini ve insülin salınımını başlatan en önemli uyaran glikozdur. Glikozun pankreas

1921 İnsülinin keşfi, Toronto Üniversitesi, Banting, Best, Collip, Macleod. (1923 Nobel Ödülü)

1922 İnsülin ilk defa insanda kullanıldı. Toronto Üniversitesi.

1925 Internasyonel İnsülin Ünitesi saptandı. 1 ünite=0.125 mg standart madde)

1926 Kristalize insülin elde edildi. Abel.

1936 İnsüline çinko eklenerek protamin zinc insülin elde edildi. Scott.

1951 Çinko insülinin asetat tamponu ile lente insülin geliştirildi. Novo.

1955 İnsülinin moleküler yapısı anlaşıldı. Sanger.

1960 Radyoimmunoassay geliştirildi. Berson Yallow.

1967 Proinsülin geliştirildi. Steiner.

1971 İnsülin reseptörleri bulundu.

1977 İnsülin geni klonlandı. Ulrich.

1978 Saflaştırılmış domuz insülini elde edildi. Eli Lilly.

1981 İnsülin reseptörünün kinaz aktivitesi tarif edildi. Kassaga.

1982 Rekombinant DNA teknolojisi ile insan insülini olan Humulin üretildi. Eli Lilly.

1982 Domuz insülinin insan insülinine enzimatik dönüşümü sağlandı.

1993 İnsülin lispro elde edildi. Jaccobs. Eli Lilly.

1995 İnsülin lispro aminoasitlerinde yapılan değişiklik ile insan insülin analoğu elde edildi. Ciszak. Eli Lilly. 
hücre metabolizmasındaki etkileri otonomik sinir sisteminin normal kolinerjik etkileri ile birleşerek beta hücrelerinden insülin sekresyonunu sağlar. İntestinal hormonlar, lösin, arjinin gibi bazı aminoasitler ve sulfonilüre grubu bazı ajanlar insülin sekresyonunu başlatır ama insülin sentezi üzerine etkileri yoktur. İnsülinin anabolik bir hormon olarak başlıca fonksiyonları; glikoz ve amino asitlerin transmembran ulaşımı, karaciğer ve iskelet kaslarında glikojen oluşumu, glikozun trigliseridlere dönüşümü, nükleik asit sentezi ve protein sentezidir. İnsülinin metabolizmadaki başlıca fonksiyonu; vücut ağırlığının üçte ikisini teşkil eden, kalp kası, fibroblast, yağ hücreleri ve çizgili kas hücreleri içerisine GLUT4 üzerinden glikoz transportunu sağlamak ve transport hızını arttırmaktır $(6,7)$.

\section{İnsülin reseptörü}

İnsülinin etkisi, insülinin hedef hücre membranının yüzeyindeki reseptörüne bağlanması ile başlar. İnsan vücudundaki farklı birçok hücrede insülin reseptörü mevcuttur. Özellikle yağ, karaciğer ve kas hücrelerinin insüline biyolojik yanıt oluşturması, insülinin bu dokulardaki reseptörüne bağlanması ile oluşur. İnsülin reseptörleri insülini hızlı, yüksek özgüllükle ve pikomolar düzeyinde bile tanıyabilecek affinitede bağlarlar. İnsülin reseptörü, tek bir gen tarafından kodlanan, iki protein subunit içeren membran glikoproteini olup, 'Büyüme Faktörü Reseptör Ailesi' üyesidir. İnsülin molekülünü bağlayan 135000 kda büyüklüğündeki alfa subuniti daha büyüktür ve tamamıyla hücre dışı yerleşimlidir. Daha küçük olan 95000 kDa büyüklüğündeki beta subunit ile alfa subunit dilsülfit bağı ile bağlıdırlar. Beta subunit hücre membranını boydan boya geçerek sitoplazmaya kadar ulaşır ve hücre içindeki kısmında özelleşmiş sinyal yolaklarını başlatan tirozin kinaz aktivitesine sahiptir (7).

\section{İnsülin Direnci}

İnsülin direnci; dolaşımda normal konsantrasyondak insüline karşı azalmış cevap olarak tanımlanır. Obez, diyabetik olmayan bireyler ve tip 2 diyabetik bireylerde insülin direnci görülebilir (8). İnsülin direncinin altında yatan patofizyolojik sebepler yeterince aydınlatılamamıştır. Genellikle insülin direncinin altında insülinin aktivite kusuru görülmektedir. İnsülin direncinin rutin klinik değerlendirmede ölçümü, öglisemik insülin klemp metodu ile yapılabilir ve böylelikle insülin fonksiyonu indirekt olarak değerlendirilmiş olur. İnsülin direncinin geniş bir spektrumu vardır. Klinik tabloda, normal glisemik değerler ve artmış insülin düzeyinden, insülin artmış olmasına rağmen hiperglisemiye kadar farklı tablolar görülebilir bu durumda hasta metabolik sendrom hastası olarak değerlendirilecektir
(9). İnsülin direnci sendromu veya değişik isimlendirmeleri ile sendrom $X$, metabolik sendrom, sayılacak bazı klinik ve laboratuvar bulguların bir arada görülmesi tablosudur. İnsülin direnci, hiperinsülinemi, obezite, dislipidemi, hipertansiyon durumları hastada bir arada görülebilir bu durumda hasta metabolik sendrom hastası olarak değerlendirilecektir. Dolayısıyla insülin direnci tespit edilen hastalar metabolik sendrom açısından değerlendirilmelidir. Metabolik sendrom ve komponentleri daha sonra daha detaylı olarak incelenecektir (10). İnsülin reseptörü ile ilişkili genlerin çeşitli mutasyonları tanımlanmıştır. İnsülin reseptör gen mutasyonu nadir görülür fakat mutasyon görülen hastalarda insülin direnci sıklığı artmıştır. Glut 4, glikojen sentaz gibi genlerde meydana gelen mutasyonlar da insülin direnci ve tip 2 diyabet gelişimi ile ilgili bulunmuştur (11). İnsülin direnci; puberte, gebelik gibi süreçlerde adaptasyon ve homeostazisi sürdürmek amacıyla geçici olarak ortaya fizyolojik bir şekilde de ortaya çıkabilir (12). İnsülin direnci, obezite, hipertansiyon gibi ek hastalıklar olmaksızın görülebilir. Obez olmayan ve glikoz toleransı normal bireylerde de insülin direnci görülebileceği gösterilmiştir (13). İnsülin direncinde, insülin reseptörünün konsantrasyonunda, afinitesinde veya her ikisinde meydana gelen anormallikler insülinin etkinliğini bozar. 'Down Regulasyon'; dolaşımda sürekli yüksek insülinin ortaya çıkardığı insülin reseptör sayısındaki azalmayı tanımlar. Muhtemelen insülinin hücre içinde artmış yıkılımı da bu tabloya eşlik etmektedir. Ancak insülin reseptörü çoğunlukla insülin duyarlılığının tek belirleyicisi değildir. Mekanizmaları henüz tam netleşmemiş olsa da insülin direnci çoğunlukla hücre içi post reseptör sinyal yolaklarının aktivasyonundan kaynaklanmaktadır. Post reseptör insülin direnci, sinyal aktarım bozuklukları ve GLUT 4 mutasyonları gibi sebeplerle ortaya çıkmaktadır. Böylelikle insülin hormonu, reseptörüne bağlanmasına rağmen, reseptör sonrası mekanizmalardaki bozukluk sebebi ile etkili olamamaktadır. Genetik yatkınlık, obezite, sedanter yaşam, yaşlanma ile insülin direncinin gelişimi artmaktadır. İnsülin direnci kilo alımı ile artarken, kilo verilmesi ile azalır. Böylelikle insülin direnci gelişiminde yağ birikiminin önemi anlaşılmaktadır. Yağ dokusunun depolama özelliği dışında sekretuar bir organ özelliği de bulunmaktadır. Adipozitlerde leptin, adiponektin, rezistin sentezlenir ve bu düzenleyici maddelerin insülin direnci gelişiminde rolü bulunmaktadır. Obezitede görülen serbest yağ asitlerinin artışı insülin direnci gelişiminde etkisi bulunmaktadır (14). İnsülin direnci gelişimi karaciğerde ve böbrekte artmış glikoz yapımı ve kasta azalmış glikoz alımı ile karakterizedir (15). Insülin direnci ve diyabet patofizyolojisinde hücresel sinyal proteinlerinin rolünü ve muhtemel klinik önemini test etmenin en iyi yollarından biri transgenik sıçan modelleri olmuştur (16). İnsülinin metabolizmada çok önemli 
bir görev üstlendiği ve aynı zamanda insülinin mutlak eksikliğinin ketoasidoza yol açtığı transgenik farelerde kanıtlanmıştır. Transgenik insülin üretim kusurlu doğan fareler doğumdan kısa bir süre sonra ketoasidoza girerek ölmüşlerdir. Heterozigot hayvanların çoğu ise klinik olarak normal bulunmuştur. Şiddetli insülin direnci ile seyreden genetik sendromlu hastalarda yapılan klinik gözlemler de bahsedilen hayvan deneyleri ile paralellik göstermektedir $(17,18)$. Heterozigot olarak insülin reseptör geni kusuru bulunanlar, klinik olarak semptom göstermezler veya sadece hafif bir glikoz intoleransı gösterirler. Bu şekildeki deney hayvanlarında heterozigot insülin reseptörüne İnsülin reseptör substrat-1 (IRS-1)'in hatalı bir aleli eklendiğinde bir post reseptör defekti eklenmesi yoluyla insülin direnci artar ve sonuçta diyabetin klinik bulguları ortaya çıkar. Bu durum transgenik poligenik hastalık modeline bir örnektir (19). Obezite, sedanter yaşam tarzı, sigara içimi, düşük doğum ağırlığı ve perinatal malnutrisyonun insülin direnci gelişimi ile ilgisi gösterilmiştir. Adipoz doku ve bu dokudan salınan hormonlar, hipotalamus-hipofiz-adrenal aks bozuklukları, ilerleyen yaş, genetik ve çevresel nedenler de insülin direnci gelişiminde etkilidir. Yakın zamanda elde edilen verilerde insülin direnci gelişiminde düşük dereceli inflamasyon gözlendiği de bildirilmiştir (20).

\section{İnsülin Direnci İle Yağ Doku Arasındaki îlişki}

Adipoz doku ile ilgili şaşırtıcı bir keşif, sadece trigliseridler için basit bir depo işlevi görmediği, aynı zamanda birçok peptid ve sitokin salgılayan aktif bir endokrin organ olmasıdır. Salgılanan peptidler arasında, leptin, adiponektin, rezistin sayılabilir. Sitokin olarak ise TNF alfa salgılandığı bilinmektedir. Leptin, rezistin ve adiponektin beyaz yağ dokudan salınarak, enerji metabolizmasını ve insülin duyarlılığını düzenler. Yağ dokunun yerleştiği lokalizasyona göre endokrin aktivitesindeki değişiklikler halen incelenmektedir (21). McGary ve arkadaşları yağ dokusu aktivitesi ile insülin direnci arasındaki ilişkiyi açıklamak için Lipotoksisite hipotezini ortaya atmışlardır. Artan yağ doku hücre içi lipit birikiminin belirli bazı hücresel sinyal yolaklarını ve fonksiyonlarını bozduğunu, böylelikle insülin direnci gelişiminde lipit birikiminin önemli rolü olduğunu iddia etmişlerdir. Yapılan hayvan deneylerinde lipit birikimi ile insülin direnci arasındaki ilişki gösterilmiştir (22). Kim ve arkadaşları transgenik lipoatrofik farelerde sinyal aktivasyonun azaldığını ve insülin direncinin görülmediğini, yağ doku transplantasyonu ile aynı hayvanlarda insülin direnci ortaya çıkabildiğini göstermişlerdir (23). Pankreas beta hücrelerindeki intraselüler lipit metabolizması, insülin sekresyonun düzenlenmesinde rol almaktadır. Hücre içi lipit homeostazisinde meydana gelen değişiklikler insülin direnci ve tip 2 diyabet gibi insülin direnci ile ilgili durumların nedeni olabilir (24). Yağ dokudan salınan leptin, rezistin ve adiponektin ile insülin direnci arasında bir ilişki olduğu açıktır. Leptin; tokluktan sorumlu olan bir proteindir. Leptin seviyeleri obezitede artar ve beyinde IL-1 salgısını arttırır, IL-6 ve TNF alfa üretiminin artmasını sağlayarak insülin direnci oluşumunda rol alır. Adiponektin; yağ dokusundan salınan ve anti-aterosklerotik özellikleri bulunan bir plazma proteinidir. Obezite ve tip 2 diyabette adiponektin düzeyleri azalır. İnsülin direnci gelişiminde ve insülin direnci sendromu komplikasyonlarının ortaya çıkmasında adiponektin düzeylerinin azalması etkilidir. Resistin: Yakın zamanda tanımlanan ve adipositlerce sentez edilen bir diğer madde PPAR (Peroxisome Proliferator Activated Reseptors; karbonhidrat ve yağ metabolizmasını düzenleyen hücre içi reseptör sistemi) sisteminin bir parçasıdır ve insülin direnci oluşumunda etkilidir $(25,26)$.

\section{İnsülin Direnci ve Beslenme}

Bir bilim olarak beslenme en geniş anlamda gıdalar ve gıdaları oluşturan besinler bilimi olarak tanımlanır ve gıdalar ile sağlık arasındaki ilişkiyi araştııır (27). İnsülin direnci ile ilişkili; metabolik sendrom, diyabet, hipertansiyon, dislipidemi, gibi hastalıkların ve komplikasyonlarının önlenmesinde ve tedavisinde beslenmenin düzenlenmesi önemli bir yer tutmaktadır. İnsülin direncinin başlangıç aşamalarındaki bireyler, beslenme düzenlenmesi ve egzersiz sayesinde ideal kilolarına ulaştıklarında ve ideal kiloyu uzun süreli koruduklarında, hipertansiyon, diyabet ve dislipidemi oluşumunun önüne geçilmesi mümkün olmaktadır (28). Kilo kontrolünü amaçlayan çok sayıda diyet modeli mevcuttur. Temel prensip, tüketilen kaloriyi kısıtlamak, karbonhidrat ve/veya protein kısıtlaması gibi makro besin dengesini sağlamak ve egzersiz programı ile desteklemektir (29). Karbonhidrat miktarı kısıtlanmış diyetlerin serum glikoz ve insülin seviyelerinde düşüşe yol açabileceği gösterilmiştir. İnsülin direncinin beslenme biçimi ile önlenmesi için karbonhidrat ve toplam kalori kısıtlaması yapılması ve düzenli egzersiz ile bu diyetin takviye edilmesi gerekmektedir (30)

\section{İnsülin Direnci ve Obezite}

Besin kaynaklarının sürekli sağlanamadığı dönemde, yaşamı sürdürebilmek için hemen kullanmak üzere intiyaçtan fazla enerji depolanması gerekmektedir. İnsan vücudundaki geniş yağ dokusu depolarında bulunan yağ hücreleri fazla enerjiyi trigliserid olarak depolamaya ve gerektiğinde hormonal ve nöral uyarılarla depolanmış enerjiyi başka bölgelerde kullanılmak üzere serbest yağ asitleri olarak serbest bırakmaya adapte olmuşlardır. Nöral ve endokrin sistem tarafından yönetilen yağ depolama 
ve kullanma sistemi uzun süreli açlığa dayanmayı sağlamaktadır. Ancak aşırı beslenme ve sedanter yaşam tarzı birlikteliğinde, bu sistem genetik faktörlerden de etkilenerek yağ enerji depolarını çok arttırır ve olumsuz sağlık sonuçlarına yol açar. Obezite yağ doku kitlesinin aşırı olması halidir. Sıklıkla obezite artmış vücut ağırığı ile eşdeğer görülse de bu yaklaşım her zaman doğru değildir. Yağ depoları dolu olmayan fakat kaslı bireylerde standardın üstünde vücut ağırlığı gözlenebilir. Obezite sıklığı günden güne artmaktadır. Kadınlarda, çocuklarda ve yoksul kesimde obezite sıklığı artışı dikkati çekmektedir. Tıbbi açıdan obezite prevelansı endişe vericidir (31). Obezite insülin direncinin en sık nedenidir. Diyabet henüz gelişmeden, obezite ve insülin direnci birlikteliği görülebilir. Beta hücre fonksiyonları bozulmamış obez bireylerde insülin direncini kompanse etmek için insülin sekresyonu artar. Obez bireylerde normal bireylere göre insülin sekresyonu üç kata kadar artış gösterir. Yüksek insülin düzeyleri hormonun etkisindeki azalmayı bir süre kompanse edebilir. Bu sayede glikoz konsantrasyonu normal bireylerle obez bireyler karşılaştırıldığında aynı dar aralıkta tutulabilir. Dolayısıyla obez bireylerde diyabet gelişimi insülin direnci gelişiminden on yıl veya daha uzun bir süre sonra gerçekleşebilir (14). Obezite basitçe alınan enerjinin tüketilenden fazla olması ile gelişir. Bu nedenle obezite tedavisinde, alınan enerji miktarının optimuma indirilmesi ve enerji tüketiminin yani fiziksel aktivitenin arttırılması ana ilkelerdir. Kalorisi çok ağır kısıtlanmış bir diyet yerine günlük 300-500 kcal arasında bir azaltma yeterli olacaktır. Fizik aktivite haftada 5-10 saat, günde 50 dakika tempolu yürüyüş şeklinde planlanmalı ve makul bir şekilde artırıımalıdır. Fiziksel aktivite ile kilo kaybı sağlanırken, doğrudan insülin direncini azaltıcı etki de görülmektedir. Yeni çalışmalar glikoz, früktoz, mısır şuruplarını içeren gıdaların fazla miktarda tüketilmesinin insülin direncini, tip 2 diyabet riskini ve obeziteyi özellikle arttırdığını göstermektedir $(32,33)$. Sonuçta obezite diyabet için önemli bir risk faktörüdür ve tip 2 diyabet hastalarının $\% 80$ kadarı obezdir. Kilo kaybı ise insülin duyarlılığını arttırırken ve diyabette serum glikoz kontrolüne yardımcı olur $(34,35)$.

\section{İnsülin Direnci ve Tip 2 Diyabet}

Diyabet, pankreasın yeterli insülin üretememesi ya da üretilen insülinin hedef dokuda görevini yapamaması sonucunda, besinlerle vücuda alınan glikozun kullanılamaması ve kan şekerinin hızla yükselmesi tablosudur. Kan şekerinin yükselmesi ile ortaya çıkan belirtilerden bazıları; aşırı susuzluk hissi, sık idrara çıkma, yorgunluk, halsizlik, açıklanamayan kilo kaybıdır. Hastalığın daha da ilerlemesi durumunda görmede değişiklikler, el ve ayakta uyuşma hissi, yara iyileşmesinde gecikme ve kaşınma hissi görünebilir. Diyabet, tüm dünyada etkili ve her yaş, cins ve ırktan milyonlarca kişiyi etkileyen bir hastalıktır (36). Tip 2 Diyabet, ABD'deki diyabet popülasyonunun \% 90'ını oluşturur. Egzersiz miktarı arttıkça ve kilo verilmesi sağlandıkça tip 2 diyabet gelişiminin önüne geçilebilir. Tip 2 diyabet gelişiminde genetik faktörler de oldukça etkilidir. Monozigot ikizlerde hastalık gelişmesi durumunda her iki bireyde de hastalık oluşumu gözlenmektedir. Hastalık oluşumunda virüslerin ve otoimmün antikorların rolü bulunmaz. Tip 2 diyabette görülen metabolik değişiklikler hastalığın insüline bağımlı Tip 1 formuna göre daha ılımlıdır çünkü yetersiz de olsa insülin salınımı devam etmektedir. İnsülin sekresyonu sayesinde ketogenez ve diyabetik ketoasidoz kısmen önlenir.

\section{Tip 2 diyabette önleme stratejileri}

Haftada 150 dakika, günlük 50 dakika yürüyüş ve benzeri egzersiz, diyet düzenlenmesi ve vücut ağırlığının \% 7'sinin kaybını içeren, egzersizi arttırma, beslenmeyi düzenleme gibi ciddi hayat tarzı değişikliklerinin tip 2 diyabeti önleme veya geciktirmede alınabilecek en etkili önlem olduğu ortaya konulmuştur. Ayrıca metformin ve troglitazon tedavisi de tip 2 diyabet gelişimini önlemiştir (37).

\section{Tip 2 Diyabette Beslenme}

Tip 2 diyabet hastalarının diyetlerinin düzenlenmesinde;

1. Günlük kalori alımı 3 ana, 3 ara öğün olmak üzere, 6 öğüne bölünerek az ve sık aralıklarla beslenmelidir.

2. Gıda sanayisinde üretilmiş, işlenmiş, şekerli yiyecek ve içeceklerden sakınılmalıdır.

3. Günlük enerji gereksiniminin yarısından fazlası karbonhidratlardan gelmeli ve bunun çoğunluğunu da posa içeriği yüksek besinler oluşturmalıdır.

4. Yağ alımı azaltılmalıdır.

5. Tuz alımı azaltılmalı, hazır gıda ve salamuralardaki tuz miktarları dikkate alınmalıdır.

6. Yemeğin yağ içeriğini arttıran kızartma, kavurma gibi hazırlama yöntemleri ile yağlı et, sakatat, kaymak, sucuk, pastırma, mayonez, krema, pasta, börek gibi yağ ve kolesterol içeriği yüksek besinlerden sakınılmalıdır.

Temel prensipler olarak kabul edilir. Diyabet tedavisinin birinci basamağı beslenme planına en iyi şekilde uyulmasıdır. Diyabetik ilaçları ya da insülini kullanmak diyet düzenlemesine uymamayı gerektirmez. Tam tersine diyet uyumu yetersiz olan hastaların kullandığı ilaçların etkisi azalabileceği gibi diyabetin diğer organ hasarlarını da hızlandıracaktır (36). 


\section{İnsülin Direnci ve Metabolik Sendrom}

\section{Metabolik sendrom}

Metabolik sendrom etyopatogenezi tam olarak aydınlatılamamış, Diyabetes Mellitus ve kardiyovasküler hastalıklar için risk faktörleri topluluğudur. Çok eskiden beri bilinmesine rağmen, henüz tanı kriterleri konusunda da tam bir görüş birliğine varılamamıştır. Dünyada ve ülkemizde erişkin toplumda metabolik sendrom sıklığı giderek artmakta, morbidite ve mortalite artışına yol açmakta, ortalamada erişkin toplumun üçte birine yakın bir oranda görünerek giderek büyüyen bir toplum sağlığı sorunu haline gelmektedir. Metabolik sendromun merkezinde insülin direnci yer almaktadır. İnsülin direnci sendromu, sendrom $X$ gibi isimlerle de adlandırılan metabolik sendroma ilk defa Reaven ve arkadaşları 1988'de dikkat çekmişlerdir. Metabolik sendrom tanı kriterleri, Türkiye Endokrinoloji ve Metabolizma Derneği tarafından 2009 yılında yayınlanan; Metabolik Sendrom Kılavuzu'ndaki hali ile tablo 2'de gösterilmiştir.

İnsülin direnci ile obezite, tip 2 diyabet, yüksek plazma trigliseritleri, düşük plazma HDL kolesterol dolayısıyla artmış kardiyovasküler risk arasındaki ilişki gösterilmiştir (10). Metabolik sendrom ilk tanımlandığından bu yana kardiyovasküler risk faktörlerine dair deneysel, klinik ve epidemiyolojik çalışmalarda elde edilen bulgular daha da netleşmiştir. İnflamasyon, fibrinoliz ve endotel disfonksiyonu gelişmesi ile kardiyovasküler risk artışının gerçekleştiği gösterilmiştir. Genetik faktörler, visseral obezite ve çevresel faktörler bir araya geldiğinde, inflamasyon, insülin direnci, endotel disfonksiyonu ve mikroalbüminüri gelişmektedir. Sonuçta dislipidemi, glikoz intoleransı, hemostaz bozukluğu, kan basıncı artışı ortaya çıkarak, kardiyovasküler hastalık riski başta olmak üzere, obezite, tip 2 diabetes mellitus, steatohepatitis ve polikistik over sendromu gibi ciddi hastalık riski artışları görülmektedir (38). Bu ilişkiler aşağıda şekil 1'de şematize edilmiştir.

Kardiyovasküler hastalık riski artışı bu hastalarda belirgindir (40). İnsülin direnci ile ilişkili olan ve nadir görülen klinik sendromlar bulunmaktadır. Tip A insülin direnci sendromu prototip olarak incelenebilir; hiperinsülinemi, akantozis nigrikans, ovaryan hiperandrojenizm ile insülin direnci birlikteliğidir (41). Metabolik sendromda insülin direnci sonucu karaciğerde basit yağ birikiminden (hepatosteatoz),

\section{Aşağıdakilerden en az biri :}

Diyabetes Mellitus

Bozulmuş glikoz intoleransı

İnsülin direnci

ve

Așağıdakilerden en az ikisi :

Hipertansiyon

Dislipidemi

Abdominal obezite
Sistolik kan basıncı > 130, diyastolik kan basıncı $>85 \mathrm{mmHg}$ veya antipertansif ilaç kullanmak

Trigliserid düzeyi $>150 \mathrm{mg} / \mathrm{dl}$ veya HDL düzeyi erkekte $<40$, kadında $<50 \mathrm{mg} / \mathrm{dl}$

Vücut kitle indeksi (VKI) > 30 veya bel çevresi: erkeklerde $>94 \mathrm{~cm}$, kadınlarda $>80 \mathrm{~cm}$ 


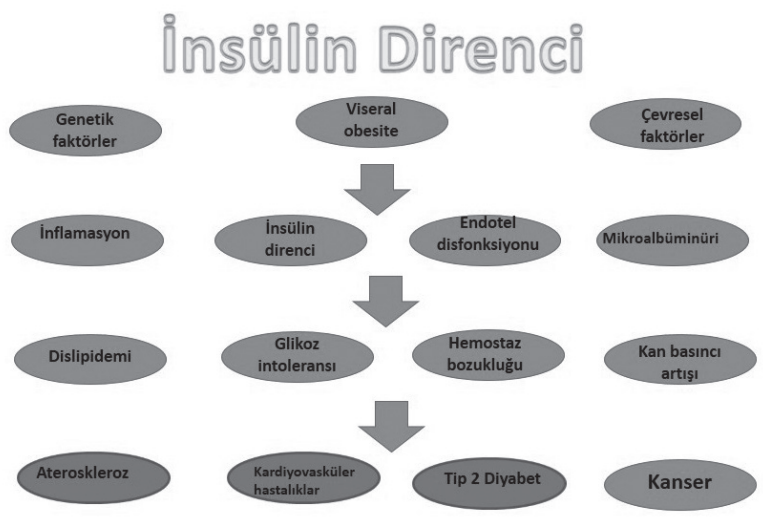

Şekil 1:

İnsülin direnci ile kardiyovasküler hastalık ve diğer riskler arasındaki bağlar

transaminaz yüksekliğine (steatohepatit), hatta siroza kadar ilerleyebilen bir seyir izler. Bu hastaların adipoz dokularından salınan ve artmış; TNF alfa, IL-6, IL-8, leptin, rezistin ve adiponektin seviyeleri görünür. Her obez hasta metabolik sendrom açısından taranmalıdır (42). Metabolik sendromlu kadın hastalarda polikistik over sendromu yönünden de değerlendirme yapılmalıdır (43). Metabolik sendrom tedavisinde ilk hedef yaşam tarzı değişikliğidir. Diyet düzenlenmesi, düzenli egzersiz yapılması yolu ile insülin direncinin geriletilmesi hedeflenmektedir.

\section{İnsülin Direncinin Etken Olabileceği Bazı Semptom ya da Hastalıklar}

\section{İnsülin direncinin endotele etkisi ve hipertansiyon}

İnsülin direnci vasküler endotelin aktif endokrin fonksiyonlarına ait dengeyi bozarak hipertansiyona yol açabilir (44).

\section{İnsülin direnci ve oksidatif stres}

Yapılan hayvan ve insan çalışmalarında, hücresel düzeyde oksidatif strese maruz kalınca, insülin sinyal iletiminin inhibisyonu gösterilmiştir. Böylelikle insülin direncinin oksidatif stres ile ilişkisi bulunmuştur (45).

\section{İnsülin direnci ve hiperkoagulabilite}

İnsülin direncinde; plasminojen aktivatör inhibitör-1, Faktör VII, Faktör VIII, von-Willebrand faktör ve fibrinojen düzeylerini yükselterek makrovasküler hastalık riskini arttırır (39).

İnsülin direnci; nörodejeneratif ve enfeksiyöz hastalıklar İnsülin direnci ile ilgili tip 2 diyabet, obezite gibi metabolik bozukluklar, sıklıkla immün bozukluk ile birliktedir. İnsülin direnci olan bireylerde nörodejeneratif hastalıkların gelişme sıklığının arttığı gösterilmiştir (46). İnsülin direnci bulunan hastalarda yapılan çalışmada enfeksiyon gelişme sıklığının arttığı gösterilmiştir (47).

\section{İnsülin direnci ve kanser}

Insülin direnci ile kanser arasındaki ilişkiye uzun yıllardır dikkat çekilmektedir. İnsülin direnci ile meme kanseri arasındaki ilişki 1992'de gösterilmiştir (48). Yapılan bir meta-analizde; insülin direnci ve kanser arasındaki ilişkiyi gösteren çok sayıda çalışma ile ilişkinin güçlü boyutları aydınlatılmıştır (49). Yapılan bir vaka kontrol çalışmasında, renal hücreli kanser ile insülin direnci arasındaki ilişki gösterilmiştir (50). Yakın tarihte yapılan çalışmalar ile insülin direnci ile ilişkisi gösterilen diğer bir kanser türü de prostat kanseridir (51). Endometrium kanseri ile insülin direnci arasında da güçlü bir ilişki gösterilmiştir (52). İnsülin direncinin çok sayıda farklı kanser türü ile muhtemel ilişkilerinin gösterilmesine karşılık, kansere yol bu ilişkiyi oluşturan moleküler mekanizmalar henüz aydınlatılamamıştır ve araştırılmaya devam edilmektedir.

İnsülin direnci ve kandaki c-peptid düzey değişiklikleri C-peptid, proinsülin yapısındaki $A$ ve $B$ zincirlerini birbirine bağlayan ve insülin sentezi esnasında, proinsülin denilen öncül maddeden koparılan bir kısımdır. Şayet normal düzeyde insülin üretimi varsa, kandaki c-peptid düzeyi de normaldir. Tip 1 DM'da pankreas tarafından üretilen insülin miktarı çok düşüktür veya yoktur ve c-peptid düzeyi de çok düşüktür. Insülin direncinin bulunduğu Tip 2 DM'da ise, c-peptid düzeyi normal veya yüksek olabilir (53).

\section{İnsülin Direncinin Ölçülmesi}

\section{Öglisemik Hiperinsülinemik Klemp}

Öglisemik hiperinsülinemik klemp metodu, De Fronzo'un tarif ettiği bir yöntemdir. Periferik insülin direncini belirlemek için altın standarttır. Testin temel prensibi hiperinsülinemik bir ortam oluşturup, bu ortamda glikoz düzeyini normal aralıkta tutmak için verilen glikozun kullanılma hızını belirlemektir. 10-12 saatlik açlık sonrası teste başlanır. Eğer hasta insülin kullanıyorsa 24 saat öncesinden orta etkili insülinler kesilir. Glikoz düzeyinin sağlıklı aralıkta tutulması insülin infüzyonu ile sağlanır, testten 2 saat sonra 
infüzyona son verilir. Girişimsel ve yapılması zor bir işlem olduğu için, özel donanım ve bu konuda deneyimli kişilerin varlığı gerektiğinden, rutinden ziyade araştırma amacıyla kullanılan çok değerli bir testtir (54)

\section{Açlık insülin düzeyi ile insülin direnci tahmini}

Açlık insülin düzeyinin de tek başına insülin direncini doğruya yakın olarak yansıtabileceğine dair çalışmalar mevcuttur. Normal glikoz toleranslı bireylerde, açlık insülin düzeyi $13 \mathrm{mikroU} / \mathrm{ml}$ olanların $\% 74$ 'ünde, $\geq 18 \mathrm{mikroU} / \mathrm{ml}$ olanların da tümünde, insülin direnci saptanmıştır. Açlıkta normal insülin düzeyi 2-10 mikroU/ml'dir (55).

\section{Oral Glikoz Tolerans Testi (OGTT)'de}

1. saat insülin düzeyi ile insülin direnci tahmini

Sağlıklı bireylerde, test edildiğinde OGTT'de, glikoz verildikten 1 saat sonra, insülin düzeyi $150 \mathrm{mU} / \mathrm{ml}$ 'nin altındadır. İnsülin direncinin ilk döneminde glikoz verilmesi sonrasında normalden daha fazla insülin salınır. OGTT'de 1. saat insülin değeri $>150 \mathrm{mU} / \mathrm{ml}$ ise insülin direnci gösterir. İnsülin dirençli hastanın daha ileri dönemlerinde bu insülin yanıtı azalır (56).

HOMA-IR (Homeostasis Model Assessment of Insulin Resistance) metodu

Öglisemik insülin klemp testinin pahalı ve zahmetli bir test olması sebebiyle klinik pratikte en sık kullanılan insülin direnci ölçüm metodu; HOMA formülüdür.

$\mathrm{HOMA}=\mathrm{Açlık}$ insülini $(\mathrm{mikroU} / \mathrm{ml})^{\star}$ Açlık plazma glikozu(mg/ dl)/405

Açlık insülin ve glikoz ölçüm sonuçları formülde yerine konularak HOMA değeri hesaplanır. Normal bireylerde HOMA değeri 2,7'den küçük olmalıdır. HOMA değeri 2,7 ve üzerinde ise değişik derecelerde insülin direncini gösterir (57-59)

\section{Sonuç}

İnsülin direnci, obezite ve abdominal yağ dokusu kitlesi ile yakından ilişkili bir metabolik bozukluktur. İnsülin direncinin patogenezine dönük yeni araştırmalara intiyaç duyulmaktadır. Genetik araştırmalar ile insülin direncinin poligenik etyolojisi açıklanmalıdır. Moleküler araştırmalar ile insülin direncinin mekanizmaları açıklanırsa önlenmesi için yeni yollar açılabilecektir. İnsülin direncinin komplikasyonları ile sinyal yolakları arasındaki güçlü ilişki her geçen gün daha fazla ortaya çıkmaktadır. Obezitenin önlenmesi ve azaltılması insülin direncini önlemek adına önemlidir. Sağlıklı görünen bireylerde insülin direnci bulunabilir. Risk grubunda olan bireylerde insülin direnci taramaları erken dönemde teşhis imkânı verebilir. İnsülin direncinin tespiti, açlık kan glikozu ve insülini ölçümü sayesinde, HOMA formülü ile kolayca yapılabilir. Erken dönemde tespiti ve diyet düzenlenmesi, düzenli egzersiz yapılması, kilo verilmesi şeklinde yașam tarzı değişikliği ile oluşacak ciddi hastalıkların önüne geçilebilir. İnsülin direncinin uzun yıllar devam etmesi ve obezitenin eşlik etmesi sonucu, tip 2 Diyabetes Mellitus, kardiyovasküler hastalıklar, hipertansiyon, kanser tablolarının biri, ikisi veya tümünün gelişmesi kaçınılmazdır.

\section{Kaynaklar}

1. Zimmet PZ, Alberti KGMM. Epidemiology of DiabetesStatus of a Pandemic and Issues Around Metabolic Surgery. Diabetes Care 2016;39(6):878-883.

2. Satman I, R Rea R, Eriksson $M$, Mosenzon $O$, Pratley R, M Baeres F, D Orsted D, F Mann J; LEADER Trial Investigators. LEADER-6: Baseline renal function and associated factors in a high cardiovascular risk type 2 diabetes population. J Diabetes Complications 2016;30(8):1631-1639

3. Gundogan NU. The Story of A Nobel Prize, The 80th Anniversary of the Discovery of Insulin. Baskent University Publication, 2001, Ankara, p: 5-55

4. Sanjeevi C.B. One hundred years of Nobel Prize and Diabete. Diabetologia 2001;44:9:37-38.

5. Gürdöl F, Ademoğlu E. Biyokimya, 2. Baskı, İstanbul, Nobel Tıp Kitabevleri 2012;238.

6. Kumar V, Cotran RS, Robbins SL. Robbins Temel Patoloji, 7. Baskı, İstanbul, Nobel Tıp Kitabevleri 2003;642.

7. David GG, Shoback D. Greenspan's Lange Temel ve Klinik Endokrinoloji, 8. Baskı, İstanbul, Güneş Tıp Kitabevleri 2009;660-667.

8. Flier JS. Lilly Lecture: syndromes of insulin resistance. From patient to gene and back again. Diabetes 1992;41:1207-19.

9. American Diabetes Assocation. Concensus Development Conference on Insulin Resistance. Diabetes Care 1998;21:310-4.

10. Reaven GM. Banting lecture 1988. Role of insülin resistance in human disease (Rewiev). Diabetes 1988;37:1595-607.

11. Almind K, Doria A, Kahn CR. Putting the genes for type 2 diabetes on the map. Nat Med 2001;7:277-9.

12. Gürlek A. İnsülin Direncinde Genetik Faktörler. Klinik Endokrinoloji. İzmir, Meta Basım 2001;49-53. 
13. Hollenbeck C, Reaven GM. Variations in insulin stimulated glucose uptake in healthy individuals with normal glucose tolerance. J Clin Endocrinol Metab 1987;64:1169-73.

14. Solymoss BC, Bourassa MG, Lespérance J, Levesque S, Marcil M, Varga S, Campeau L. Incidence and clinical characteristics of the metabolic syndrome in patients with coronary arter disease. Coron Artery Dis 2003;14:207-12.

15. Champe PC, Harvey RA, Ferrier DR. Biyokimya Lipincott, 3. Baskı. İstanbul, Nobel Tıp Kitapevleri 2007;340-345.

16. Mauvais-Jarvis F, Kulkarni RN, Kahn CR. Knockout models are useful tools to dissect the patophysiology and genetics of insulin resistance. Clin Endocrinol 2002;57:1-7.

17. Accili D, Drago J, Lee EJ, Johnson MD, Cool $\mathrm{MH}$, Salvatore $\mathrm{P}$, et al. Early neonatal death in mice homozygous for a null allele of the insulin receptor gene. Nat Gen1996;12:106-9.

18. Joshi RL, Lamothe B, Cordonnier N, Mesbah K, Monthioux E, Jami J, et al. Targeted disruption of the insülin reseptor gene in the mouse results in neonatal lethality. EMBO J 1996;15:1542-7.

19. Brüning JC, Winnay J, Bonner-Weir S, Taylor SI, Accili D, Kahn CR. Development of a novel polygenic model of NIDDM in mice heterozygous for IR and IRS-1 null alleles. Cell 1997;88:561-72.

20. Das UN. Minireview: Is metabolic syndrome $X$ an inflammatory condition? Exp Biol Med 2002;227(11):989-97. 21. Montagne CT, O'Rahilly S. The perils of portliness causes and consequences of visceral adiposity. Diabetes 2000;49:883-8.

22. McGary JD. Dysregulation of fatty acid metabolism in the etiology of the type 2 diabetes. Diabetes 2002;51:7-18. 23. Kim JK, Gavrilova O, Chen Y. Mechanisms of insulin resistance in a ZIP/17-1 fatless mice. Biol Chem 2000;276:8456-60.

24. Boden G, Shulman GI. Free fatty acids in obesity and type 2 diabetes: defining their role in the development of insulin resistance and beta cell dysfunction. Eur J Clin Invest 2002;32:S13:14-23.

25. Özata M, Yönem A. Endokrinoloji Metabolizma ve Diyabet. İstanbul, İstanbul Medikal Yayıncılık 2006;553-55. 26. Howell KR, Powell TL. Effects of maternal obesity on placental function and fetal development. Reproduction. 2017;153(3):97-108.

27. Salway J.G. Metabolizma Atlası Bir Bakışta Metabolizma, 3. Baskı, İstanbul, İstanbul Tıp Kitabevi 2012;112.

28. Yenigün M. Her Yönüyle Diabetes Mellitus, 2. Baskı.
İstanbul, Nobel Tıp Kitabevi 2001;51.

29. Shils ME. Modern Nutrition in Health and Disease, 9. Baskı, Lippincott Williams and Wilkins, 1999;121-129.

30. Li G, Zhang P, Wang J. The long-term effects of lifestyle interventions to prevent diabetes in the China Da Qing Diabetes Prevention Study: a 20 year follow-up study. Lancet 2008;371:1783-1789.

31. Lowe MR, Miller-Kovach K, Frye N. An initial evaluation of a commercial weight loss program: short-term effects on weight, eating behavior, and mood. Obes Res 1999;7:51-59.

32. American Diabetes Association. Standards of medical care in diabetes-2011. Diabetes Care 2011;34:11-61.

33. Jameson JL. Harrison Endokrinoloji, 16. Baskı, İstanbul, Nobel Tıp Kitabevi 2009;268-271.

34. Schulz MB. Sugar -sweetened beverages, weight gain and incidence of type 2 diabetes in young and middle-aged women. JAMA 2004; 292:927-34.

35. Sencer E, Orhan Y. Beslenme, 1. Baskı, İstanbul, İstanbul Medikal Yayıncılık 2005;560-562.

36. Haffner S, Taegtmeyer H. Epidemic obesity and the metabolic syndrome. Circulation 2003;30:108(13):1541-5.

37. Buchwald H, Avidor Y, Braunwald E, Jensen MD, Pories $\mathrm{W}$, Fahrbach $\mathrm{K}$, et al. Bariatric surgery: A systematic review and meta-analysis. JAMA 2004;13:292(14):1724-37.

38. Özenoğlu A, Hatemi HH. Diabette Beslenme. İstanbul, İstanbul Medikal Yayıncılık 2004;11-18.

39. Lavin N. Lippincott Williams \& Wilkins. Endokrinoloji ve Metabolizma El Kitabı, 3. Baskı, İstanbul, Güneş Kitabevi 2006;105-116.

40. McFarlane SI, Banerji M, Sowers JR. Insulin resistance and cardiovascular disease. J Clin Endocrinol Metab 2001;86:713-18.

41. Metabolik Sendrom Kılavuzu, Türkiye Endokrinoloji ve Metabolizma Derneği, , Ankara, Tuna Matbaacılık 2009;1-25.

42. Expert panel. Executive summary of the third report of the National Cholesterol Education Program (NCEP) expert panel on detection, evaluation and treatment of high blood cholesterol in adults. JAMA 2001;285:2486-97.

43. Burtis CA. Ashwood ER. Bruns ED. Tietz Textbook of Clinical Chemistry and Molecular Diagnostics, Fourth Edition. Elsevier Saunders 2006;445-592.

44. Satman I, Yilmaz T, Sengül A, Salman S, Salman F, Uygur S, et al. Population-based study of diabetes and risk characteristics in Turkey: results of the Turkish diabetes epidemiology study (TURDEP). Diabetes Care 2002;25(9):1551-6.

45. McMurray F, Patten DA, Harper ME. Reactive Oxygen 
Species and Oxidative Stress in Obesity-Recent Findings and Empirical Approaches. Obesity (Silver Spring) 2016;24(11):2301-2310.

46. Kaidonvich-Beilin O. Crosstalk between metabolic and neuropsychiatric disorders. F1000 Biol Rep 2012;4:14. doi: 10.3410/B4-14.

47. Jeon CY, Haan MN, Cheng C, Clayton ER, Mayed ER, Miller JW. Helicobacter Pylori infection is associated with an increased rate of diabetes. Diabetes care 2012;35:520-25.

48. Brunning PF, Bonfrer JM, Von Noord PA, Hart A, de Jong Bakker $\mathrm{M}$. Insulin resistance and breast cancer risk. Int J Cancer 1992;21:52(4):511-16.

49. Byers T, Sedjo RL. Does international weight loss reduce cancer risk? Diabetes Obesity Metabolism 2011;13:1063-72. 50. Spyridopoulos TN, Dessypris N, Antoniadis AG, Gialamas S, Antolopoulos CN, Katsifoti K, et al. Insulin resistance and risk of renal cancer. A case control study. Hormones 2012;11:308-15.

51. Ma J, Li H, Giovanucci E, Mucci L, Qiu W, Nguyen PL, et al. Prediagnostic body-mass index, plasma $C$ peptide concentration and prostate cancer. Spesific mortality in men with prostate cancer; a long term survival analysis. Lancet oncology 2008;9:1039-47.

52. Wang $\mathrm{Y}$, Hua S, Tian W, Zhang L, Zhao J, Zhang $\mathrm{H}$, et al. Mitogenic and anti-apoptotic effects of insulin in endometrial cancer are phosphatidylinositol 3-kinase. Gynecologic Oncology 2012;125:734-741.

53. Pearson ER. Personalized medicine in diabetes: the role of 'omics' and biomarkers. Diabet Med 2016;33(6):712-7.

54. De Fronzo RA, Tobin JD, Andres R. Glucose clamp technique: a methodfor quantifying insulin secretion and resistance. Am J Physiol 1979;237(3):214-23.

55. Hermans MP, Levy JC, Morris JC, Turner RC. Comparison of tests of beta-cell function across a range of glucose tolerance from normal to diabetes. Diabetes 1999;48(9):1779-86.

56. Kidson W. Policystic ovary syndrome: a new direction in treatment. MJA1998;169:537-40.

57. Mathews DR, Hesken YP, Rudenski AS, Naylor BA, Treocher DF, Turner RC. Homeostasis Model AssesmentInsulin resistance and beta cell function from fasting plasma glucose and insulin concentration in man. Diabetologic 1985;28(7);412-419.

58. Pick A, Clark J, Kupstrup C, Levisett M, Pugh W, BonnerWeir S, et al. Role of apoptosis in failure of beta cell mass compensation for insulin resistance and beta cell defects in the male zucker diabetic fatty rat. Diabetes 1998;47:358-364.
59. Powell K. The two faces of fat. Nature 2007;447:525527. 